\title{
Analysis of Domestic Resources Cost Based on Farm Typology of Bali Cattle in Plampang Sumbawa Regency, West Nusa Tenggara
}

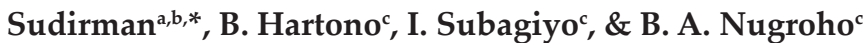 \\ ${ }^{a}$ Graduate Student of Animal Science Faculty, Brawijaya University \\ ${ }^{b}$ Faculty of Animal Science and Fisheries, Samawa University \\ Jalan Semongkat KM 1, Sumbawa Besar, NTB, Indonesia \\ 'Faculty of Animal Science, Brawijaya University \\ Jalan Veteran Malang, Jawa Timur, Indonesia \\ *Corresponding author: dirman.unsa@gmail.com \\ (Received 06-01-2018; Reviewed 04-05-2018; Accepted 26-07-2018)
}

\begin{abstract}
The objectives of the study were to analyze the use of Domestic Resources Cost based on the most prevalent typology of Bali cattle farm and to analyze the economic efficiency based on the typology of Bali cattle farm in Plampang Sub-district Sumbawa Regency, West Nusa Tenggara (NTB). The study was carried out in Plampang Sub-district, Sumbawa Regency in 2017, with 53 respondents selected randomly and the key respondents were head of farms UPT, extension workers, inter-island traders, agricultural equipment traders, as well as agricultural materials and medicines traders. The respondents were acquired by applying systematic random sampling based on the farm typology with survey method and analyzed by the analysis of Domestic Resource Cost and analysis of Policy Analysis Matrix. There were three most prevalent farm typologies of Bali cattle production system used by the farmers in Plampang Sub-district, Sumbawa Regency, West Nusa Tenggara. The most prevalent production systems were: a typology of 6 months grazed (June-November) and 6 months confined (December-May) which was called with an acronym as 66 typology, typology of tethered throughout the year called as tethered typology, and typology of confined throughout the years called as confined typology. Bali cattle comparative advantage based on the farm typology as shown by Domestic Resource Cost Ratio (DRCR) values were 0.28 in 66 typology, 0.48 in tethered typology, and 0.31 in confined typology. It means that to save Rp. 100 is required the domestic factor cost Rp. 28 of 66 typology; Rp. 48 of tethered typology, and Rp. 31 of confined typology. Thus, it can be concluded that if domestic beef from Bali cattle is produced domestically, it will save the foreign exchange as much as $72 \%$ of 66 typology; $54 \%$ of tethered typology; and $69 \%$ of confined typology based on the import costs that must be spent. The competitive advantage is shown by the PCR values of 0.32 in 66 typology, 0.46 in tethered typology, and 0.35 in confined typology.
\end{abstract}

Keywords: competitiveness, comparative advantage, competitive advantage, prevalence

\section{INTRODUCTION}

Beef is a livestock product and one of the main foods of the Indonesian people. The imbalance in the rate of meat consumption with meat production is the reason that Indonesia still imports beef (Harmini et al., 2011). Yuzaria \& Suryadi (2011) stated that Indonesia has the opportunity to become a source of world beef cattle only by utilizing comparative advantage, and increasing competitiveness, at least to meet domestic demand. In the long period, a breakthrough is needed in increasing domestic production, namely optimizing the area of beef cattle development through a regional approach. The results of the Nalle et al. (2017) stated that the domestic resource costs of beef cattle in the Upper Benain-Noelmina watershed area, the Domestic Resource Cost Ratio (DRCR) value is 0.29 grazing; 0.60 tethering; and Private Cost Ratio (PCR) value of 0.41 grazing; 0.71 tethering. While the results of the Yani et al. (2017) study reported that in the downstream area of the Moyo Watershed in Sumbawa District, the DRCR value was 0.24 nursery typology; 0.37 savings typology; 0.33 combination typology and PCR value of 0.27 nursery typology; 0.41 savings typology, and 0.31 combination typology.

One of the strategic areas for the development of beef cattle farms, especially Bali cattle in NTB, namely Sumbawa Regency, is an area that specifically has potential natural resources and breeders' resources that support the development of Bali cattle business. In general, Bali cattle production in Sumbawa Regency adopts grazing and tethering systems. The Bali's cattle business is unique with many maintenance typologies in Plampang, thus it is important to investigate the most 
prevalent typology about the cost of domestic resources and the efficiency of Bali cattle business based on its typology.

There is rare information about the profile of Bali cattle production system based on the farm typology in Plampang. In addition, explicitly, it is hard to find any report deal with the research focused on the Bali cattle comparative advantage conducted in this research location refers to the typology approach. Policy Analysis Matrix (PAM) is a method of analysis that can be applied to measure comparative advantage using Domestic Resources Cost Ratio (DRCR) as well as comparative advantage measured by the value of Private Cost Ratio (PCR) (Alves et al., 2017). The use Domestic Resources Cost (DRC) as indicator in measuring the comparative advantage of Bali cattle is relevant to the question of why Indonesia has not met domestic beef demand in national level as is shown by the dependency of imported cattle or beef. Therefore, the analysis of comparative advantage namely DRC is applied to measure how many domestic resources are needed or spent in producing output value added, either bigger or lower than that of value added of the result.

Problem statements of the research are 1) to which level the use of domestic resources cost based on the most prevalent and typology of Bali cattle farm, and 2) to which level the efficiency of Bali cattle farm based on the farm typology in Plampang, Sumbawa Regency, West Nusa Tenggara (NTB). The study objectives were to analyze the use of Domestic Resources Cost based on the most prevalent typology of Bali cattle farm and to analyze the efficiency based on the typology of Bali cattle farm in Plampang Sub-district Sumbawa Regency, West Nusa Tenggara (NTB).

\section{METHODS}

The research location was determined purposively in Plampang Sub-district on the consideration as one of the center producers of breeding cattle and beef cattle in the eastern region of Sumbawa Regency. The sample villages were chosen purposively, namely the villages of Plampang, Selante, and Muer on the basis of livestock density criteria, namely (1) low, (2) moderate, and (3) high (Chander et al., 2011) with the rural criteria were low, moderate, and high densities when the density of livestock were $<0.25,0.25-1$, and $>1 \mathrm{AU} /$ ha of farm area range, respectively.

Respondents were Bali cattle farmers with livestock production system using (1) 66 typology, (2) tethered typology, and (3) confined typology. Fifty-three farmers were selected randomly as the respondents. Specifically, there were 15 respondents from Selante Village, 20 respondents from Plampang Village, and 18 respondents from Muer Village. Meanwhile, the number of respondents varied based on the typology, such as 28 respondents with 66 typology, 9 respondents with tethered typology, and 16 respondents with confined typology. Furthermore, the key respondents that were the head of UPT of farms, extension workers, inter-island traders, agricultural equipment traders, agricultural traders, and medicines traders were determined purposively.

\section{Domestic Resources Cost (DRC) Analysis}

Domestic Resources Cost (DRC) is a non-tradable factor input value that uses an activity for each unit of value added of tradable value added. DRC is used to measure how much one unit of foreign exchange can be saved if a commodity is produced domestically. Elsedig et al. (2015) states that the calculation of the cost of domestic resources is based on net social benefits by the following formula:

$$
\mathrm{DRCn}=\frac{\sum_{s=2}^{m} d s n V s+E n}{(U n-i n-r n)}
$$

Note: $D R C n$ is the net social profit of a farm activity; $U n$ is the total value of the activities of a business at global market level counted in US\$; in is the total value of imported intermediate inputs, either direct or indirect used in farm activities counted in US\$; $r n$ is the total value of the income of the owner of the foreign inputs used in the activities of a business, either directly or indirectly counted in US\$; VS is the price of each primary input unit used in a farm counted in IDR; $d s n$ is the total domestic input used in a farming business; $E n$ is the effect of externality activities of a farm.

The ratio between the value of DRC and the currency exchange rate shadow (V1) called DRC Ratio (DRCR), can be written as follows:

$\mathrm{DRCR}=(\mathrm{DRC}$ Value $) / \mathrm{V} 1$

or formulated as follows:

$\mathrm{DRCR}=\mathrm{DRC} / \mathrm{SER}$

Note: $D R C R$ is the ratio of the domestic resources cost based on the social price in IDR; DRC is the domestic resources cost based on social price in IDR; and SER is the shadow price of social exchange rate value in IDR/US\$

\section{Policy Analysis Matrix (PAM) and Sensitivity Analysis}

Policy analysis matrix, efficiency, and domestic resources cost were explained in Table 1 . The measurement of sensitivity analysis was the sensitivity of the IDR exchange rate that measured the impact of exchange rate changes on private profitability and comparative advantage by using two possible exchange rates on an official basis of the exchange rate between February and July 2017. The first option was assumed by the $10 \%$ depreciation of exchange rate and the second option was the $10 \%$ appreciation of exchange rate. The determination of $10 \%$ implied that in long-term it was assumed that other factors were ceteris paribus. At the research time, it refered to the value of exchange rate (1-US\$) started in February until July 2017 with levels of the exchange rate were shown in Table 2.

\section{RESULTS}

\section{Farmers Characteristics}

There were 18 typologies of Bali cattle production systems found in Plampang, West Nusa Tenggara with three most prevalent farmers: (1) 6 months grazed (JuneNovember) and 6 months confined (December-May) or abbreviated to 66 typology; (2) tethered throughout 
Table 1. Policy analysis matrix, efficiency, and domestic resources cost

\begin{tabular}{|c|c|c|c|c|}
\hline \multirow{2}{*}{ Indicators } & \multirow{2}{*}{ Acceptance } & \multicolumn{2}{|c|}{ Cost } & \multirow{2}{*}{ Advantages } \\
\hline & & Tradable input & Domestic factor & \\
\hline Private price (market) & $\mathrm{A}$ & $\mathrm{B}$ & $\mathrm{C}$ & $\mathrm{D}$ \\
\hline Social price (economy) & $\mathrm{E}$ & $\mathrm{F}$ & G & $\mathrm{H}$ \\
\hline Divergency (transfer) & $\mathrm{I}=\mathrm{A}-\mathrm{E}$ & $\mathrm{J}=\mathrm{B}-\mathrm{F}$ & $K=C-G$ & $\mathrm{~L}=\mathrm{D}-\mathrm{H}$ \\
\hline \multicolumn{5}{|l|}{ Efficiency and comparative advantage: } \\
\hline Private profitabilities & \multicolumn{2}{|c|}{$\mathrm{D}=\mathrm{A}-\mathrm{B}-\mathrm{C}$} & & \\
\hline Social profitabilities & \multicolumn{2}{|c|}{$\mathrm{H}=\mathrm{E}-\mathrm{F}-\mathrm{G}$} & & \\
\hline Private Cost Ratio (PCR) & \multicolumn{2}{|c|}{$\mathrm{PCR}=\mathrm{C} /(\mathrm{A}-\mathrm{B})$} & & \\
\hline Domestic Resources Cost Ratio (DRCR) & \multicolumn{2}{|c|}{$\mathrm{DRCR}=\mathrm{G} /(\mathrm{E}-\mathrm{F})$} & & \\
\hline \multicolumn{5}{|l|}{ Policy distortion and market failure: } \\
\hline Output Transfer (OT) & \multicolumn{2}{|c|}{$\mathrm{I}=\mathrm{A}-\mathrm{E}$} & & \\
\hline Input Transfer (IT) & \multicolumn{2}{|c|}{$\mathrm{J}=\mathrm{B}-\mathrm{F}$} & & \\
\hline Factor Transfer (FT) & \multicolumn{2}{|c|}{$\mathrm{K}=\mathrm{C}-\mathrm{G}$} & & \\
\hline Net Policy Transfer (NT) & \multicolumn{2}{|c|}{$\mathrm{L}=\mathrm{D}-\mathrm{H}=\mathrm{I}=\mathrm{I}-\mathrm{J}-\mathrm{K}$} & & \\
\hline Nominal Protection Coefficient on Output (NPCO) & \multicolumn{2}{|c|}{$\mathrm{NPCO}=\mathrm{A} / \mathrm{E}$} & & \\
\hline Nominal Protection Coefficient on Input (NPCI) & \multicolumn{2}{|c|}{$\mathrm{NPCI}=\mathrm{B} / \mathrm{F}$} & & \\
\hline Effective Protection Coefficient (EPC) & \multicolumn{2}{|c|}{$\mathrm{EPC}=(\mathrm{A}-\mathrm{B}) /(\mathrm{E}-\mathrm{F})$} & & \\
\hline Profitability Coefficient (PC) & \multicolumn{3}{|c|}{$P C=(A-B-C) /(E-F-G)$ or $D / H$} & \\
\hline Subsidy Ratio to Producer (SRP) & \multicolumn{3}{|c|}{$\mathrm{SRP}=\mathrm{L} / \mathrm{E}=(\mathrm{D}-\mathrm{H})$} & \\
\hline
\end{tabular}

Source: Alves et al. (2017); Vavrina \& Basovnikova (2015); de Souza et al. (2017); Stalgiene et al. (2017)

Table 2. The exchange rates of IDR to US\$ started in February until July 2017

\begin{tabular}{lc}
\hline Date & Value of IDR \\
\hline February 1, 2017 & $13,374.68$ \\
March 1, 2017 & $13,399.00$ \\
April 2, 2017 & $13,317.50$ \\
May 1, 2017 & $13,335.77$ \\
June 1, 2017 & $13,294.65$ \\
July 2, 2017 & $13,332.24$ \\
Average (at the research time) & $13,342.48$ \\
\hline
\end{tabular}

1) February $13^{\text {rd }}$ was IDR $13,374.68 ; 2$ ) March $1^{\text {st }}$ was Rp. $13,399.00$

the year or abbreviated to tethered typology; and (3) confined throughout the year or abbreviated to confined typology. There was a difference in the marketing management of livestock from each typology. The 66 typology sold cattle to fulfill urgently needs such as for children education payment, marriage, health, going hajj, and others. Tethered typology sold cattle whenever they wanted to sell and if the price was adequate. In confined typology, they sold cattle mainly as finisher beef cattle.

The farmers in the production system of Bali cattle farm had a similar condition in harvesting feed resources and fed pattern. In the 66 typology, the farmers' activities in agriculture was finished in June-November, so the cattle could be released freely in the rice fields, moor, and forest with a source of feed derived from agricultural waste and natives grass. Bali cattle began to be raised in the cattle-shed before the planting took place with the aim that livestock did not disturb the farmers' crops. Cattle feed during the months of December-January (rainy season) usually had been provided before by the farmers by collecting their own or purchasing rice straw and green bean straw. Feed for the months of February to May was in the form of native grass or legumes that grew well at the surrounding of the cattle-shed. In the tethered typology, the feed was obtained by the cattle by grazing the grass around the tethering area and the additional feed was provided by the farmers by cutting and carrying either native grass or leguminous trees. In the beginning of the rainy season, the cattle were fed with rice straw and mung bean straw. In confined typology, cattle were fed feeds in the form of forages consisted of native grass, Elephant grass, Leucaena leucocephala, and Glyricidia sepium.

Table 3 illustrates the livestock ownership in 66 typology is $50 \%$ (5-10 AU), tethered typology is $66.67 \%$ (1-4 AU), and confined typology is $62.50 \%$ (11-15 AU). While the dominant educational levels of elementary school graduates in 66 typology, tethered typology, and confined typology were $71.43,100 \%$, and $87.50 \%$, respectively. The livestock ownership was not related to the level of education but related to the age factor that in 66 typology $42.86 \%$ of the owners of livestock were at the ages of 30-39 years, in the tethered typology, $100 \%$ of the owners were at the ages of 30-39 years, and in confined typology, $75 \%$ of the owners were at the ages of $40-50$ years. The age factor determined the decision of the farmers to take risks in determining the farm typology and the farm-scale.

\section{Domestic Resource Cost (DRC) Analysis Comparative Advantages}

Figure 1 shows the value of DRCR for 66 typology, tethered typology, and confined typology are $0.28,0.48$, and 0.31 , respectively. The value of DRCR describes that the three typologies have a comparative advantage which have provided economic benefits and there is a saving of foreign exchange. DRCR is a ratio of compara- 
Table 3. Profile of farmers in the Plampang Sub-district, Sumbawa Regency, NTB

\begin{tabular}{|c|c|c|c|c|}
\hline \multirow{2}{*}{ Criteria } & \multirow{2}{*}{ Indicators (\%) } & \multicolumn{3}{|c|}{ Farm typology } \\
\hline & & 66 & Tethered & Confined \\
\hline \multirow[t]{3}{*}{ Age (years) } & $30-39$ & 42.86 & 100 & - \\
\hline & $40-50$ & 39.29 & - & 75.00 \\
\hline & $51-60$ & 17.86 & - & 25.00 \\
\hline \multirow[t]{5}{*}{ Education level } & Unfinished elementary school & - & - & - \\
\hline & Elementary school graduates & 71.43 & 100 & 87.50 \\
\hline & Junior high school graduates & 10.71 & - & 12.50 \\
\hline & Senior high school graduates & 17.86 & - & - \\
\hline & College graduates & - & - & - \\
\hline \multirow[t]{3}{*}{ Number of family member (person) } & $1-2$ & 35.71 & 66.67 & 37.50 \\
\hline & $3-4$ & 60.71 & 33.33 & 62.50 \\
\hline & $5-6$ & 3.57 & - & - \\
\hline \multirow[t]{4}{*}{ Raising experience (years) } & $1-4$ & 7.14 & 66.67 & 25.00 \\
\hline & $5-10$ & 60.71 & 33.33 & - \\
\hline & $11-15$ & 7.14 & - & 37.50 \\
\hline & $16-20$ & 25.00 & - & 37.50 \\
\hline \multirow[t]{3}{*}{ Moor land ownership (Ha) } & $0.5-0.9$ & 28.57 & 33.33 & 37.50 \\
\hline & $1-2$ & 64.29 & 66.67 & 62.50 \\
\hline & $3-4$ & 7.14 & - & - \\
\hline \multirow[t]{5}{*}{ Beef cattle origin } & Bought & 53.57 & 66.67 & 62.50 \\
\hline & Inherited & 35.71 & 33.33 & 12.50 \\
\hline & Sharing system (Kadasan) & 3.57 & - & - \\
\hline & Given by the government & 3.57 & - & - \\
\hline & Buffalo barter & 3.57 & - & 25.00 \\
\hline \multirow[t]{4}{*}{ Beef cattle ownership (AU) } & $1-4$ & 25.00 & 66.67 & 25.00 \\
\hline & $5-10$ & 50.00 & 33.33 & 12.50 \\
\hline & $11-15$ & 7.14 & - & 62.50 \\
\hline & $16-20$ & 17.86 & - & - \\
\hline \multirow[t]{4}{*}{ Marketing } & Butcher & 3.57 & - & - \\
\hline & Broker & 39.29 & 100 & 62.5 \\
\hline & Middle-men & 53.57 & - & 37.5 \\
\hline & Among farmers & 3.57 & - & - \\
\hline
\end{tabular}

Source: Primary processed data (2017)

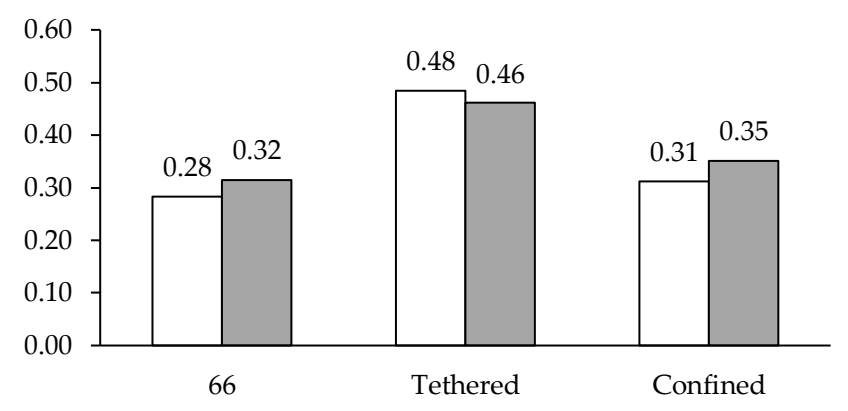

Figure 1. Domestic resource cost ratio (DRCR, $\square$ ) and private cost ratio $(\mathrm{PCR}, \mathbf{\square})$ values of Bali cattle farm in Plampang

tive advantage indicators, in calculating the number of domestic resource costs that can be saved to produce one foreign exchange unit. If the DRCR value is $<1$, the economic activity is economically efficient or has a comparative advantage, and if DRCR $>1$, the economic activity shows that the social use of domestic resources is greater or there is a waste of domestic resources. Bali cattle breeders in Plampang Subdistrict have a comparative advantage shown by the DRCR value of 0.28 of the 66 typology; 0.48 tethered typology; and 0.31 confined typology, meaning to save Rp. 100 domestic factor costs Rp. 28 of the 66 typology; Rp. 48 tethered typology, and Rp. 31 confined typology. The comparative advantages of the three typologies of cattle farm business are available since the breeders in Plampang Sub-district use feed resources from pasture available in the moorland, gardens, and forests. Labor used 2-3 hours per day so that the labor cost was low; about Rp7,500/hour and daily use only 1-2 unskilled labors.

\section{Competitive Advantages}

Figure 1 illustrates that the PCR values in 66 typology, tethered typology, and confined typology were $0.32,0.46$, and 0.35 , respectively. PCR values for the three business typologies indicate that cattle farmers in the Plampang area are able to finance their domestic factors at private prices and thus have a comparative advantage. Some of the advantages possessed by breed- 
ers in Sumbawa Regency are the use of land as a place of the farm which is done together in the joint pasture in the form of moor owned by the farmers and government's forest land. The cost of land in each farm typology in the animal unit (AU) per year are Rp230,925.05, Rp138,888.89, and Rp202,127.66 in 66 typology, tethered typology, and confined typology, respectively. The feed consist of native grass in the pasture and leaves from legume trees in the garden and in the forest, and the remaining agricultural waste in the field moor are freely available. Feeds that were purchased directly by the farmers only rice straw and green bean straw with the price in rupiah per animal unit per day (IDR/AU/day) were Rp533.70, Rp576.13, and Rp286.66 in 66 typology, tethered typology, and confined typology, respectively.

\section{PAM Analysis of Bali Cattle Farm Business}

Table 4 shows that the cattle farmers earn income from cattle farms such as calf, cattle breed, young bull, and beef cattle. Farmers in using tradable input as in
Table 4 according to the farm typology have no difference, namely in the form of wire rope, bucket, flashlight, machetes, nylon rope, and drugs. The farmers using tradable inputs are not based on the farm economicscale (cattle ownership) because the use of tradable inputs as work aids such as buckets, flashlights, machetes, wire ropes, and sickles are only used at any time, while nylon ropes and medicines are adjusted with the ownership of cattle.

Figure 2 shows the farmers' benefits for all three farm typologies. The farmer gained a private benefit at the levels of Rp6,175,098.07, Rp5,055,342.77, and Rp5,798,045.72 in 66 typology, tethered typology, and confined typology, respectively. Figure 2 also illustrates the divergence of farmers' profits. Farmers of 66 typologies gained the biggest negative profit by Rp862,535.02, then the tethered typology had a positive profit by Rp519,211.17, and the confined typology had a negative profit by Rp955,903.58. The differences in the profits gained by the farmers for each typology are related to the different use of domestic factors i.e., Rp54,494.89;

Table 4. Private price and social input output of Bali cattle farm in Plampang Sub-district

\begin{tabular}{|c|c|c|c|c|c|c|c|}
\hline \multirow{3}{*}{ Input / output } & \multirow{3}{*}{ Unit (Farm) } & \multicolumn{6}{|c|}{ Farm business typology } \\
\hline & & \multicolumn{2}{|c|}{66} & \multicolumn{2}{|c|}{ Tethered } & \multicolumn{2}{|c|}{ Confined } \\
\hline & & Private & Social & Private & Social & Private & Social \\
\hline \multicolumn{8}{|l|}{ Input tradable } \\
\hline OVD & Rp/AU/Year & $10,000.00$ & $20,500.00$ & $10,000.00$ & $20,500.00$ & $10,000.00$ & $20,500.00$ \\
\hline \multicolumn{8}{|l|}{ Domestic factors } \\
\hline Labor & Rp./AU/JOK/Year & $657,480.08$ & $657,480.08$ & $2,505,353.32$ & $2,505,353.32$ & $1,327,659.57$ & $1,327,659.57$ \\
\hline Land & Rp./AU/Ha/Year & $230,925.05$ & $230,925.05$ & $138,888.89$ & $138,888.89$ & $202,127.66$ & $202,127.66$ \\
\hline Bank interest & \%/AU/Year & $887,474.63$ & $887,474.63$ & $890,207.62$ & $890,207.62$ & $904,167.50$ & $904,167.50$ \\
\hline CR barn & Rp./AU/Year & & & & & & \\
\hline A. Bamboo & & $3,705.60$ & $3,705.60$ & - & - & 769.43 & 769.43 \\
\hline B. Wood & & - & - & - & - & $9,078.01$ & $9,078.01$ \\
\hline C. Live fence & & $6,352.46$ & $6,352.46$ & - & - & $1,210.40$ & $1,210.40$ \\
\hline D. Rope wire & & 370.87 & 352.33 & - & - & 206.91 & 206.91 \\
\hline E. Barbed wire & & $5,188.64$ & $5,028.99$ & - & - & - & - \\
\hline F. Zync & & - & - & - & - & $19,669.03$ & $3,706.86$ \\
\hline G. Tile & & - & - & - & - & - & - \\
\hline H. Fees & & $14,293.05$ & $14,293.05$ & - & - & $3,258.77$ & $3,258.77$ \\
\hline Feed & Rp./AU/Day & & & & & & \\
\hline A. Forage & & $2,000.00$ & $2,000.00$ & $1,234.57$ & $1,234.57$ & $1,211.58$ & $1,211.58$ \\
\hline B. Dry & & 533.7 & 533.7 & 576.13 & 576.13 & 285.66 & 285.66 \\
\hline $\begin{array}{l}\text { Livestocks' drinking } \\
\text { water }\end{array}$ & Rp/AU/Day & - & - & - & - & - & - \\
\hline CR tools & Rp./AU/Year & & & & & & \\
\hline A. Machete & & $7,157.33$ & $6,203.02$ & $14,814.81$ & $12,839.51$ & $11,347.52$ & $9,607.57$ \\
\hline B. Flashlight & & $6,347.06$ & $5,077.65$ & $11,111.11$ & $8,888.89$ & $8,510.64$ & $6,638.30$ \\
\hline C. Bucket & & - & - & $3,703.70$ & $3,111.11$ & $3,309.69$ & $2,780.14$ \\
\hline D. Rope & & 500 & 366.67 & $7,000.00$ & $5,833.33$ & $4,000.00$ & $3,000.00$ \\
\hline Transportation & Rp./AU/Year & $87,500.00$ & $33,333.33$ & $87,500.00$ & 33333.33 & $87,500.00$ & $33,333.33$ \\
\hline Livestock handling & & $50,000.00$ & $20,000.00$ & $50,000.00$ & $20,000.00$ & $50,000.00$ & $20,000.00$ \\
\hline Etc. & Rp./AU/Year & - & - & - & - & - & - \\
\hline \multicolumn{8}{|l|}{ Output } \\
\hline Young bull & Rp./AU/Year & $10,042,857.14$ & $9,532,280.48$ & $10,500,000.00$ & $9,532,280.48$ & $10,000,000.00$ & $9,532,280.48$ \\
\hline Breed cattle & Rp./AU/Year & $8,048,387.10$ & $8,112,438.40$ & $8,333,333.33$ & $8,112,438.40$ & $7,928,571.43$ & $8,112,438.40$ \\
\hline Beef cattle & Rp./AU/Year & $7,765,060.24$ & $11,865,350.59$ & & & $7,888,888.89$ & $11,865,350.59$ \\
\hline
\end{tabular}

Notes: OVD (drugs, vaccines, vitamins, disinfectants), CR (Capital recovery)

Source: Primary processed data 2017. 


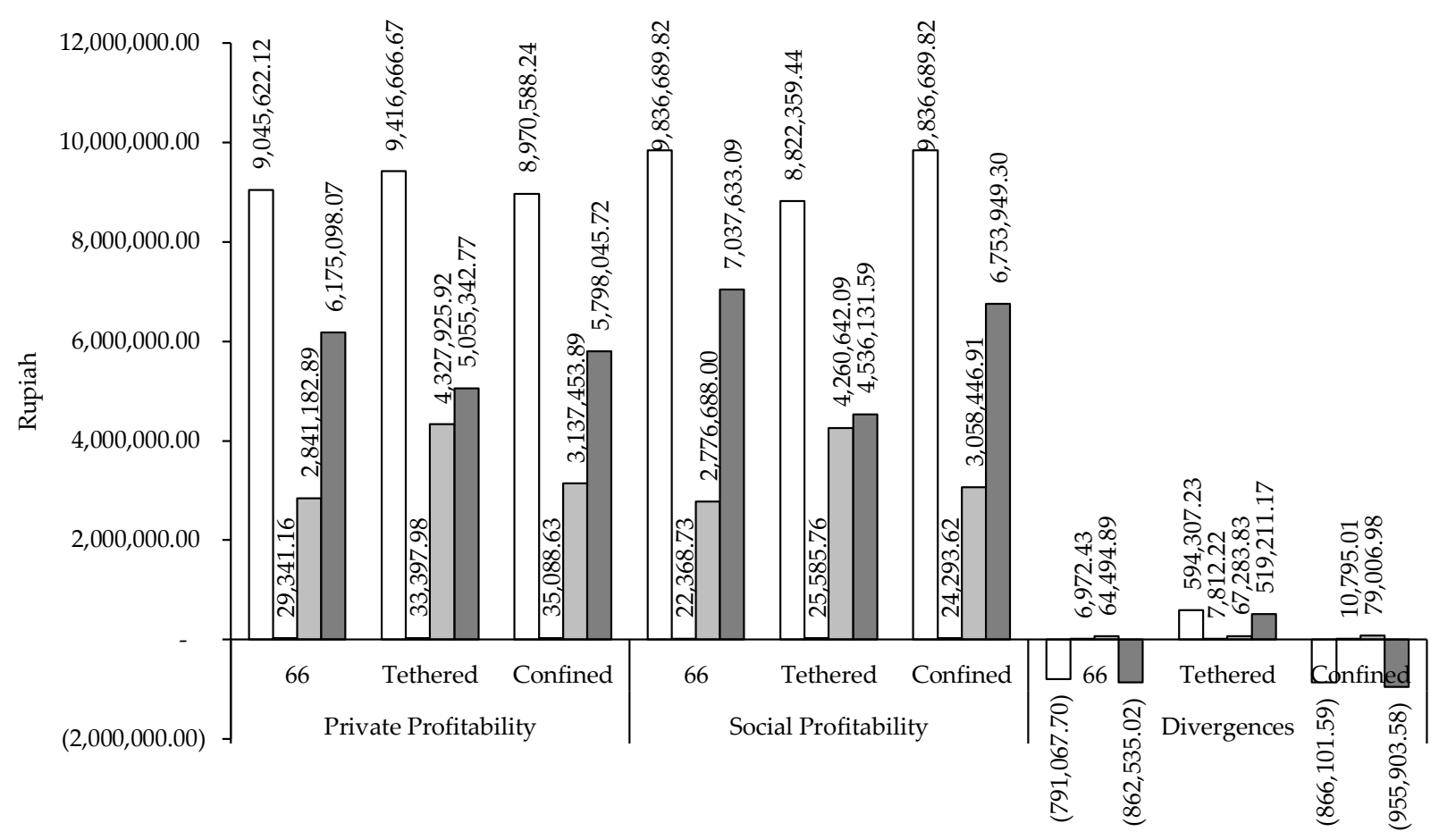

Figure 2. Revenue, benefits, and divergences of Bali cattle farm in Plampang Sub-district ( $\square$ Revenue, $\square$ Input Tradable, $\square$ Input Non Tradable, $\square$ Profits ).

Rp67.283,83, and Rp79,006.98 in 66 typology, tethered typology, and confined typology, respectively. Farmers in tethered typology gained positive divergence of profits. However, due to the low selling price of cattle, the divergence of profits was small. In contrast, the confined typology had the determination of import prices of beef cattle that was too high and had a negative divergence of profit due to the inadequate selling prices of cattle.

PAM analysis results illustrate the effect of divergence that causes actual prices to differ from their social prices. Divergences arise due to market failures and policy distortions, as shown in Figure 3.

Figure 3 also illustrates the impact of government policy on Bali cattle farm business in the Plampang Subdistrict based on the following farm typology:

1. Output policy of cattle farm business based on the typology of NPCO value were 0.92 in 66 typology, 1.07 in tethered typology, and 0.91 in confined typology. Differences in the value of NPCO between the farm typology of business were related to the determination of the price of output, especially for tethered typology. Farmers in tethered typology, they sell cattle breeds and young bull with the higher prices because of the government policy on the procurement of livestock and seeds for NTB-BSS and Pijar program in Plampang Sub-district. NTB$B S S$ is a program of one million cattle in West Nusa Tenggara. Besides, Pijar is an integration program covering three advantage commodities namely cattle, maize, and seaweed. In case of the 66 typology and confined typology, the farmers sell beef cattle, therefore, the determination of the price of imported cattle is too high.
2. Input policy based on the farm business typology of NPCI value are 1.31, 1.31, and 1.44 in 66 typology, tethered typology, and confined typology, respectively. Based on the farm typology of business, Bali cattle farmers in the Plampang area receive higher domestic input prices because of all domestic input goods are produced outside the Regency of Sumbawa so that the domestic input prices are already burdened by the existing tax policy.

3. Input-output policy: Based on the farm typology of business, the farmers get an input-output policy with EPC values that are 0.92, 1.07, and 0.91 in 66 typology, tethered typology, and confined typology, respectively. Tethered typology farmers get output prices above their efficiency because the selling price of breed cattle and the young bull are influ-

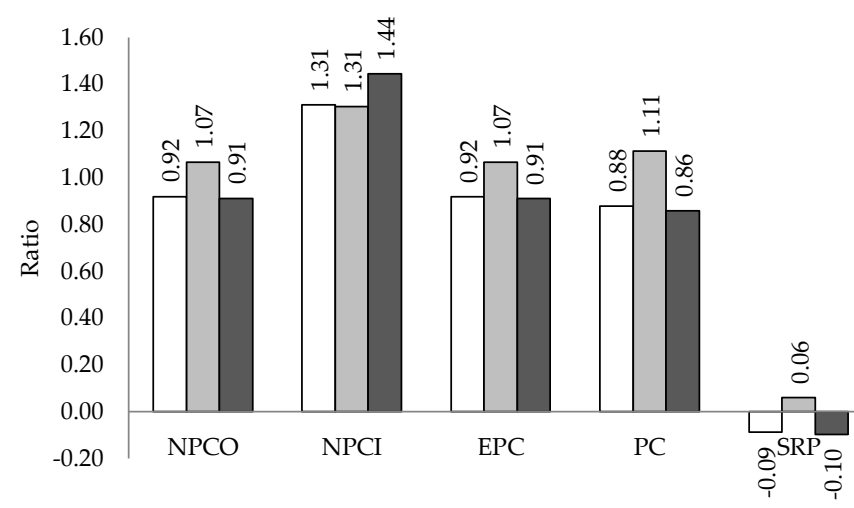

Figure 3. Government policy impact indicators of Bali cattle farm in Plampang Sub-district $(\square 66, \square$ Tethered, $\square$ Confined). 
enced by the government's policy in the procurement of cattle breed and the young bull. Further, the beef cattle of the 66 typology and confined typology are handed over to the market price.

4. Profit coefficient: Bali cattle farmers in the Plampang Sub-district get farm business profit coefficients with the PC value of $0.88,1.11$, and 0.86 in 66 typology, tethered typology, and confined typology, respectively. The farmers of tethered typology get incentives from the government, mainly in determining the selling price of breed cattle and the young bull. Furthermore, the 66 typology and confined typology do not get incentives from the government in determining the beef cattle selling price.

5. The indicator of subsidy on producers: In this case, the cattle farmers in Plampang Sub-district get subsidy indicator with SRP values of $-0.99,0.06$, and -0.10 in 66 typology, tethered typology, and confined typology, respectively. The farmers of the three business farm typologies have gained influence from the government's policy of procuring cattle for breed cattle support programs to the other cattle farmers groups in Sumbawa Regency where the procurement must be from Sumbawa Regency itself.

\section{Sensitivity Analysis}

Figure 4 illustrates that when the rupiah depreciates (weakens), it makes the value of DRCR decreases in all business farm typologies, resulting in a comparative advantage increasing by 0.02 for all typologies. The value of PCR did not change due to the rise and fall of the rupiah values, meaning that the exchange rate changes did not affect the comparative advantage of the cattle farm business in the Plampang Sub-district, Sumbawa regency. Dwi \& Nuhfil (2010) reported their research on comparative and competitive advantages of apple farming in Poncokusuma Malang that the fluctuation of the rupiah exchange rate against the dollar in apple farming only affected its comparative advantage while its competitive advantage remained.

\section{DISCUSSION}

Emelda et al. (2014) and Rouf et al. (2014) report that Asian countries including Indonesia import young bulls because they have a comparative advantage in producing beef cattle, due to the availability of agro-industry by-products and relatively low labor wages. Guzek et al. (2015) and Lowenstein et al. (2016) state that the comparative advantages of the livestock sub-sector are contributed by the potential of livestock resources and natural resources in providing feed.

Typology of Bali cattle farm in Plampang area based on the value of DRC is still better than some areas in Indonesia that are close to one or weak comparative advantage, such as cattle farm business in Bandung has DRC of 0,54 (Yuzaria \& Suryadi, 2011) and in Sungai Puar, Agam District, West Sumatra has high DRC of 0.94, in Bojonegoro District has DRC of 1.04 (Lestari et al. 2017), and Jember District has DRC of 0.44 (Toni et al., 2014).

Rauf et al. (2014) states that based on the results of research in several regions in Indonesia it is concluded that most of the beef cattle farm businesses in some regions of Indonesia have comparative advantage, i.e., in Jambi DRC is 0.54 (Muthalib et al., 2010), in Central Lampung DRC is 0,55, and in Magetan, East Java DRC is 0.94 (Thornton, 2010). Differences in the level of comparative advantage are affected by several differentiating factors such as input and output factor prices, as well as input-output coefficients of beef cattle production such as the amount of feeding, labor demand, and productivity of beef cattle.

Vavrina \& Basovnikova (2015) state that the comparative advantage of a farm is closely related to the carrying capacity of production factors such as land, natural resources, labor, capital and infrastructure, and the dynamic ability to create added value for efficient use of production factors.

The comparison of DRCR and PCR values for 66 typology and confined typology were smaller (DRCR $<$ PCR), meaning that government policy has not been able to affect its economic efficiency because of the purchase price of cattle breed and young bull are higher

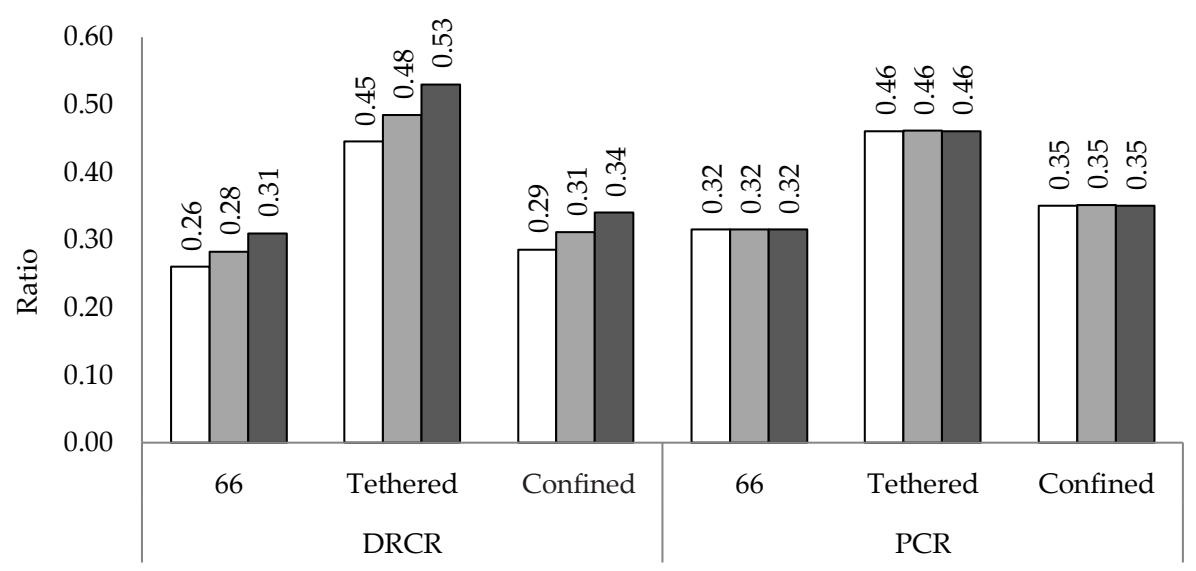

Figure 4. Domestic resource cost ratio (DRCR) and private cost ratio (PCR) rates to exchange rates of Bali cattle farm in Plampang ( $\square$ 14,676.72 Up 10\%, $\square$ 13,342.48 Research, $\square$ 12,008.23 Down 10\%). 
than the price of imported bulls (Figure 1). Tethered typology has the value of DRCR>PCR, meaning that government policy has effectively influenced its economic efficiency, especially the fixing of livestock prices below the prices of imported bulls. Yani et al. (2017) states that if the comparison value is $\mathrm{PCR}<\mathrm{DRCR}$, then the strategy in the ongoing regulation is sufficient to be maintained.

The use of domestic factors by farmers is same according to the typology of investment capital, barn making, feed, labor, land, and drinking water (Figure 3). Farmers used the following domestic factors such as capital investment, barn, feed, labor, land, cattle drinking water, transportation and livestock handling, and output.

Capital Investment. Capital investment refers to the calculated cost of capital recovery cost (CRC) of barns, equipment, and fixed assets (Colmenar-Santos et al., 2016). The largest initial capital was the cost of initial cattle purchases. However, the capital will be returned when the cattle are sold. Barns establishment and equipment procurement are calculated in accordance with the economic age in each component because every year the barn and equipment are always on hold maintenance (Sadri et al., 2018). Durable components such as bamboo can only be used for a year while the other components have an average economic life of 2-3 years. Therefore the value of the CRC is calculated from the purchase price of these components in addition to bank interest (12\%). The uses of investment capital from the three farm typologies were adjusted to the economic scale of the farm (cattle ownership) and the cattle for tethered typology and confined typology were originated from offsprings produced and bought, while for 66 typology, the cattle were originated either from their own offspring and bought or from sharing system known as kadasan, government aid, and barter with buffalo.

The results of the study are in line with the results of Yani et al. (2017) stating that the largest initial capital is the cost of purchasing livestock, but the capital will return when the livestock are sold. The number of livestock ownership also influences the use of investment capital, differences in yield. The research is the origin of livestock as breeding animals, wherein the Plampang sub-district seeds are originating from the results of fellow breeders, government assistance and buffalo livestock exchanged with cattle. Plampang was previously a barn for buffalo cattle, however there was a shift from buffalo cattle to Bali cattle because the cattle were considered to be faster to breed.

Barn. In 66 typology, barn components were made of living fences, a kind of plant called kayu Jawa, bamboo, barbed wire, and wire rope with the size of the barn is quite large because the average number of Bali cattle ownership was 8.82 AU with an average barn area of $12.95 \mathrm{~m}^{2}$ and the barns were without roof because the model is open. The barns functioned from December to May since during this period the farmland began to be planted with rice, maize, and other crops called palawija. In the period of June to November, the cattle are re-released to the joint pasture such as moor, rice field, and forest. Private prices and social components of the bamboo and live fences are in accordance with actual prices at the research location i.e., bamboo is Rp7,000/stem and live fence is Rp1,000/rod. For wire rope, machete, bucket, barbed wire, and the nylon rope, private prices are taken from the actual market price at farmer level (actual price), while their social prices are estimated by reducing divergence occurs such as government policy and market failure. Further, the tethered typology on average does not have a barn because its production system is moved and it has small-scale of cattle ownership. Moreover, the tethered typology has no barn since its production system done by tethering and moving the cattle and the business is a small scale. Then, the confined typology has barns with an open construction and has a tin roof. Suwiti et al. (2017) stated that the construction of cattle barns should be based on local agroecosystems, maintenance objectives, and cattle physiological status. The cattle barn model in the highlands is designed to protect the cattle from the cold weather but for the lowland area, the barn is a more open enclosure.

Feed. Private and social prices of the feed components of agricultural wastes in moorlands, forage from pasture, and rice straw in rice fields provided in the barn has the same value because no component is produced elsewhere (Daioglou et al., 2015). The assumption of feed cost calculation is rice straw in the calculation of the cost of procurement, fresh grass in farmers moor and joint pasture for six months released in the count based on the cattle daily needs that is $10 \%$ of live-weight multiplied with the price of fresh grass around Rp. $200.00 / \mathrm{kg}$. The straw of palawija on farmers' moor area is calculated based on the requirement of dry material (DM) of $2.5 \%$ cattle liveweight multiplied with the price of palawija straw. In tethered typology, the feed is obtained by the tethered cattle and the additional feed is provided by the farmers obtained by cutting and carrying both native grass and leguminous trees (Pan et al., 2015). At the beginning of the rainy season, the cattle are fed with rice straw and green bean straw. In confined typology, the cattle are fed with feed in the form of forage such as native grass, elephant grass, and the leaves of Leucaena leucocephala and Glyricidia sepium.

The study by Nalle et al. (2017) reports that the type of feed given and consumed by beef cattle in the Upper Benain-Noelmina watershed area, $100 \%$ is a type of forage feed and without the provision of concentrate. The results of the study showed that Bali cattle in Plampang gave forage, as well as rice straw and peanut straw in the dry season. The different types of feed given and forage prices will affect the cost of input of domestic resources from these feed ingredients. Rouf et al. (2014) stated that the competitiveness of beef cattle business was determined by many factors, including potential resources such as feed, cattle, labor, technology, and market demand.

Labor. The labor force used is generally a family workforce which is mostly not paid but is calculated as a contribution to the effort carried out. Nalle et al. (2017) states that private wage and social labor rates are set 
equally, assuming that the level of skills/ skills of workers in rural areas is generally low. However, when the workforce is employed, it is economically the cost that has been spent due to not having the opportunity to do other work, so that the workforce must also be calculated as a component of costs. The labor used is generally unskilled labors. Calculation of working hours of labors (JOK or jam orang kerja) showed an average of 3 hours/ day to provide drinking water and cutting feed. The number of labor involved is between 1-3 people with a ratio of 1 women and 1-2 men.

All typologies used family labor, labor used were adjusted to food crop farming activities, those were Rp. $60,000 /$ male working day (HKP) or 8 hours/day with details of Rp. 7,500/hour. The 66 typology required 1 (one) male workforce to monitor the grazing fields in the dry season for 3 hours per week for 6 months and 1-2 workers in the planting season with the details of 3 hours per day for 6 months. The tethered typology required 2-3 people with 4 hours/day working hours (morning, evening and night) and the confined typology was 3 hours/day. All family members were involved in raising livestock, both feeding, looking for food and providing drinking water. The 66 typology was the most efficient compared to other typologies with the least social costs and social typology, Rp. 657,480.08/JOK/year.

Land. Land used is moor that can only be planted once a year with commodities of rice, corn, and green beans. Muller \& Robertson (2013) states that the shadow price of the land can be estimated by using the rent calculated each season. This study used the social price of land calculated equal to the actual rental price of Rp. 750,000/ ha/year. The three typologies of the Bali cattle farm in Sumbawa Regency have an economic-scale of the farm in accordance with the area of land owned, therefore the 66 typology of land tenure is greater than the tethered typology and confined typology so that the social cost of feed forage is greater. Petroman et al. (2012) reported that farmers using grazing systems could increase the production of forage twice since grazing could encourage the recovery of pasture and could prevent the spread of weeds because with the assistance of cattle's nails the seeds can enter the soil and germinate. Wahyuni (2015) states that the benefits of agricultural land for farmers are as a benefit from the results of farming activities and innate benefits. The congenital benefits of agricultural land are forages.

Drinking water of cattle. Drinking water for cattle is not taken into account because the farmers have a source of drinking water for the cattle such as wells, puddles, and small rivers.

Transportation and livestock handling. Transportation in one way to the port of delivery in private 2-3 tails because cattle raising is not concentrated in social transportation up to 8 tails centered before distributed to farmers. The cost of transportation and livestock handling in one way is equal to that borne by the animal unit (AU) in private is higher than the social.
Output. The outputs of 66 typology and confined typology for the young bull, breed cattle, and beef cattle, while tethered typology only to young bull and breed cattle. The value of private cattle, especially young bull and breed cattle is higher than in social, this is because of the policy of local government in the procurement of young bull and breed cattle to be given to groups of farmers through the aid program BSS which origin of seeds should not come from outside the region and prices have been set higher earlier. While the value of beef cattle in private is lower than in this society because there is no government intervention in selling beef cattle.

The three typologies (66 typology, tethered typology, and confined typology) have a positive profit, indicating that the farms are able to compete at the actual price level including the impact of policy distortions and market failures. Tandi (2010) reported the results of research that Bali cattle in Pattallasang Sub-district with grazing system was feasible to be cultivated economically and can be upgraded to family main business. Luanmase et al. (2011) reported that the success of livestock business was not separated from the factors of age, education level, livestock-raising experience, risk taker's courage, allocation of work time, the number of family dependents, cattle ownership, and the availability of the forage.

\section{CONCLUSION}

Bali cattle farmers in Plampang Sub-district of Sumbawa Regency, West Nusa Tenggara in their farm businesses are using three most prevalent farm typologies, which are: (1) 66 typology, (2) tethered typology, and (3) confined typology. Comparative advantage of Bali cattle based on the farm business typology as shown by the respective DRCR value of 0.28 in 66 typology, 0.48 in tethered typology, and 0.31 in confined typology. Comparative advantage shown by the PCR values of 0.32 in 66 typology, 0.46 in tethered typology, and 0.35 in confined typology.

\section{CONFLICT OF INTEREST}

We certify that there is no conflict of interest with any financial, personal, or other relationships with other people or organization related to the material discussed in the manuscript.

\section{REFERENCES}

Alves, C. E. S., L. C. Belarmino, \& A. D. Padula. 2017. Feedstock diversification for biodiesel production in Brazil: using the policy analysis matrix (PAM) to evaluate the impact of the $\mathrm{PNPB}$ and the economic comparative advantage of alternative oilseeds. Energy Policy. 109: 297-309. https://doi. org/10.1016/j.enpol.2017.07.009

Chander, M., B. Subrahmanyeswari, R. Mukherjee, \& S. Kumar. 2011. Organic livestock production: an emerging opportunity with new challenges for producers in tropical countries. Rev. Sci. Tech. 30: 969-83. https://doi. org/10.20506/rst.30.3.2092

Colmena-Santos, A., E. Rosales-Asensio, D. Borge-Diez, \& E. 
Collado-Fernandez. 2016. Evaluation of the cost of using power plant reject heat in low-temperature district heating and cooling networks. Appl. Energ. 162: 892-907. https:// doi.org/10.1016/j.apenergy.2015.10.161

Daioglou, V., E. Stehfest, B. Wicke, A. Faaij, \& D.P. van Vuuren. 2015. Projections of the availability and cost of residues from agriculture and forestry. GCB Bioenerg. 8: 2 . https://doi.org/10.1111/gcbb.12285

de Souza, A. R. L., J. P. P. Revillion, P. D. Waquil, L. C. Belarmino, \& B. A. Lanfranco. 2017. Economic and accounting evaluation of rice milled production chains in Rio Grande do Sul (Brazil) and Uruguay with application of the policy analysis matrix. Cienc. Rural. 47: 1-7. https:// doi.org/10.1590/0103-8478cr20151085

Department of Animal Husbandry \& Animal Health Sumbawa Regency. 2017. Data Visualization Animal Husbandry Sumbawa Regency 2016. Sumbawa NTB.

Dwi, R. A. \& H. Nuhfil. 2010. Analysis of comparative advantage and competitive farming of Apples in the district ofAnalisis keunggulan komparatif dan kompetitif usahatani apel (Mulus sylvetris Mill) di Kecamatan Poncokusumo, Kabupaten Malang Regency. AGRISEgrise. 10: 62-76.

Elsedig, E. A. A., M. I. Mohd, \& M. A. Fatimah. 2015. Assessing the comparative advantage and comparative advantage of broiler production in Johor using policy analysis matrix. Int. Food. Res. J. 22: 116-121.

Emelda, A., L. Asrul, \& P. Mappigau. 2014. An analysis of comparative advantage and government policies impact on development of cocoa farming in Indonesia. Asian J. Agric. Rural Dev. 4: 30-35.

Guzek, D., D. Glabska, K. Gutkowska, J. Wierzbieki, A. Wozniak, \& A. Wierzbicka. 2015. Influence of cut and thermal treatment on consumer perception of beef in polish trials. Pak. J. Agri. Sci. 52: 521-526.

Harmini, R.W., Asmarantaka, \& J. Atmakusuma. 2011. Model dinamis sistem ketersediaan daging sapi nasional. Jurnal Ekonomi Pembangunan. 12: 128-146

Lestari, R. D., L. M. Baga, \& R. Nurmalina. 2017. Daya saing usaha penggemukan sapi potong peternakan rakyat di kabupaten Bojonegoro, Jawa Timur. Buletin Peternakan. 41: 101-112. https://doi.org/10.21059/buletinpeternak. v41i1.16906

Lowenstein, C., W. F. Waters, A. Roess, J. H. Leibler, \& J. P. Graham. 2016. Animal husbandry practices and perceptions of zoonotic infectious disease risks among livestock keepers in a rural Parish of Quito, Ecuador. Am. J. Trop. Med. Hyg. 95: 1450-1458. https://doi.org/10.4269/ ajtmh.16-0485

Luanmase, C. M., S. Nurtini, \& F. T. Haryadi. 2011. Motivation analysis of cattle breeding for local farmers and transmigration and its effect on revenue in district Kairatu of West Seram Regency. Buletin Peternakan. 35: 113-123. https:// doi.org/10.21059/buletinpeternak.v35i2.598

Muller, C. \& R. D. Robertson. 2013. Projecting future crop productivity for global economic modelling. Agric. Econom. 45: 37-50. https://doi.org/10.1111/agec.12088

Musnandar, E., R. A. Muthalib, D. Firmansyah, \& E. Musnandar. 2010. Dampak kebijakan pemerintah terhadap daya saing dan efesiensi serta keunggulan kompetitif dan komparatif usaha ternak sapi rakyat di kawasan sentra produksi Propinsi Jambi. Jurnal Penelitian Universitas Jambi: Seri Humaniora. 12: 55-62.

Muthalib, R.A., D. Firmansyah, \& E. Musnandar. 2010. Dampak kebijakan pemerintah terhadap daya saing dan efesiensi serta keunggulan kompetitif dan komparatif usaha ternak sapi rakyat di kawasan sentra produksi Propinsi Jambi. Jurnal Penelitian Universitas Jambi: Seri Humaniora. 12: 55-62.
Nalle, A. A., B. Hartono, B. A. Nugroho, \& H. D. Utami. 2017. Domestic resources cost analysis of smale-scale beef cattle farming at upstream area of Benain-Noelmina Watershed, West Timur, East Nusa Tenggara. De Gruyter Open, Open Agriculture 2:417-424.

Pan, S-Y., M. A. Du, I-T. Huang, I-H. Liu, E-E. Chang, \& P-C. Chiang. 2015. Strategies on implementation of wasteto-energy (WTE) supply chain for circular economy system: a review. J. Clean. Product. 108: 409-421. https://doi. org/10.1016/j.jclepro.2015.06.124

Petroman, C., I. Petroman, M. Diana, S. Coman, A. Dumitrescu, C. Statie, \& D. Avramescu. 2012. Quality management in ecological beef production. Internasional Journal for Quality Research. 6: 207-212.

Rouf, A. A., A. Daryanto, \& A. Fariyanti. 2014. Daya saing usaha sapi potong di Indonesia: Pendekatan Domestic Resources Cost. Wartazoa 24: 97-107.

Sadri, A. M., S. V. Ukkusuri, S. Lee, R. Clawson, D. Aldrich, M.S. Nelson, J. Saipel, \& D. Kelly. 2018. The role of social capital, personal networks, and emergency responders in post-disaster recovery and resilience:a study of rural communities in Indiana. Nat. Hazards.90: 1377-1406. https:// doi.org/10.1007/s11069-017-3103-0

Stalgiene, A., A. Jedik, A-H. Viira, \& A. Krievina. 2017. Market power in Lithuanian, Latvian and Estonian dairy sectors: the case of raw milk market. Transform. Buss. Econom. 16: 89-105.

Suwiti, N. K., I. N. K. Besung, \& G. N. Mahardika, F. Frandy, M. Hartono, \& S. Suharyati. 2017. Factors influencing conception rate of the Bali cattle in the district of Pringsewugrowth hormones levels of Bali cattle in Bali, Nusa Penida, and Sumbawa Islands, Indonesia. Scientific Journal of Integrated Animal Husbandry Vet. World. 3: 239-244.

Tandi, I. 2010. Analisa ekonomi pemeliharaan ternak sapi Bali dengan sistem penggembalaan di Kecamatan Pattallassang Kabupaten Gowa Sulawesi Selatan. Jurnal Agrisistem. 6: 13-21.

Thornton, P. K. 2010. Livestock production: recent trends, future prospects. Philosophical Transactions B. 365: 2853-2867.

Toni, H., H. S. Teguh, Q. Nurul, \& Oktarina. 2014. Management increasing comparative advantage of local beef for the forest fringe communities. J. Bus. Manag. (IOSR-JBM). 16: 40-43.

Wahyuni, R. 2015. The control structure of land resources and contributions receivable of the beef cattle, against farmers household income beef cattle business resources and land tenure: cattle business performance income farmers contribution. Widyariset. 18: 79-90.

Vavrina, J. \& M. Basovnikova. 2015. Comparative advantage of family farms in the Czech Republic in the context of EU Common Agricultural Policy 2014+. Acra Universitatis Agriculturae et Silviculturae Mendelianae Brunesis. 63: 2171-2178. https://doi.org/10.11118/actaun201563062171

Yani, A., B. Hartono, B. A. Nugroho, \& H. Nugroho. 2017. The cost analysis of domestic resources of the Bali cattle business: the case study in Moyo watershed downstream Sumbawa Regency, West Nusa Tenggara. Asian J. Microbiol. Biotechnol. Environ. Sci. 19: 189-1998.

Yuzaria, D. \& D. Suryadi. 2011. Analisis tingkat keuntungan, keunggulan kompetitif, keunggulan komparatif dan dampak kebijakan impor pada usaha peternakan sapi potong di Propinsi Jawa Barat. Jurnal Agripet. 11: 32-38. https:// doi.org/10.17969/agripet.v11i1.652 